This technique could be useful for ischemic mitral regurgitation in patients who have localized dyskinesis in the posterior left ventricular wall.

\section{References}

1. Liel-Cohen N, Otsuji Y, Vlahakes GJ. Functional ischemic mitral regurgitation can persist despite ring annuloplasty: mechanistic insights. Circulation. 1997;96:I-540.

2. Dor V, Sabatier M, Di Donate M, Montiglio F, Toso A, Maioli M. Efficacy of endoventricular patch plasty in large postinfarction akinetic scar and severe left ventricular dysfunction: comparison with a series of large dyskineteic scars. J Thorac Cardiovasc Surg. 1998;116:50-9.

3. Frater RMW, Cornelissen P, Sisto D. Mechanism of ischemic mitral insufficiency and their surgical correction. In: Vetter HO, Hetzer R, Schmutzler H, editors. Ischemic mitral incompetence. New York: Springer-Verlag; 1991. p. 117-30.

4. Raman J, Dixit A, Storer M, Buxton BF. Geometric endo-ventricular patch repair of inferior left ventricular scars improves mitral regurgitation and clinical outcome. Ann Thorac Surg. 2001;72(suppl):S1055-8.

5. Kron IL, Green GR, Cope JT. Surgical relocation of the posterior papillary muscle in chronic ischemic mitral regurgitation. Ann Thorac Surg. 2002;74:600-1.

\title{
The intraoperative "ink test": A novel assessment tool in mitral valve repair
}

\author{
Ani C. Anyanwu, MD, FRCS, and David H. Adams, MD, New York, NY
}

$\mathrm{M}$ itral valve repair is the established therapy of choice for most patients with mitral regurgitation. Assessment of repair quality traditionally relies on visual inspection, saline testing, and transesophageal echocardiography (TEE). Although invaluable in assessing valve competency, the saline test is limited because it does not provide confirmation of the surface of coaptation; a valve that is competent on saline testing might actually have a minimal surface of coaptation or excess anterior leaflet tissue below the closure line. Although TEE might demonstrate such imperfections (specifically inadequate zone of coaptation or a tendency for systolic anterior motion), there is an understandable reluctance to reinstitute cardiopulmonary bypass to address such TEE findings if the valve is otherwise competent. Such a strategy, however, leaves some patients with an inadequate surface of coaptation and might be one explanation for recurrent mitral regurgitation. ${ }^{1}$ There is a need for a technique that allows the surgeon to confirm the amount of leaflet tissue below the valve closure line before weaning from cardiopulmonary bypass. We describe a simple "ink test," which allows an accurate assessment (and optimization) of the surface of coaptation during mitral valve reconstruction.

From the Department of Cardiothoracic Surgery, Mount Sinai Hospital, New York, NY.

Received for publication Dec 7, 2006; revisions received Dec 22, 2006; accepted for publication Jan 8, 2007

Address for reprints: David H. Adams, MD, Department of Cardiothoracic Surgery, Mount Sinai Medical Center, 1190 Fifth Ave, Box 1028, New York, NY 1028 (E-mail: David.Adams@mountsinai.org).

J Thorac Cardiovasc Surg 2007;133:1635-6

$0022-5223 / \$ 32.00$

Copyright $\odot 2007$ by The American Association for Thoracic Surgery doi:10.1016/j.jtcvs.2007.01.035

\section{Technique}

At completion of valve reconstruction, a saline test is performed by using a bulb syringe to inject saline into the ventricular cavity until the mitral leaflets are distended and in an approximate systolic position. Assuming no residual leaks are identified (which should first be corrected by appropriate techniques), the detached tip of a surgical gentian violet marking pen (Codman, Raynham, Mass) is held with a clamp and used to mark the line of closure from the anterior to the posterior commissure, leaving a residual reference line on both leaflets (Figures 1, A, and 2, A). Optimally, one should see a symmetric line of closure displaced toward and parallel to the posterior aspect of the annuloplasty ring. The saline is then aspirated from the ventricle, allowing inspection of each leaflet. The height of the residual leaflet below the marked closure line represents the leaflet available to create the surface of coaptation (Figure 1, B, and 2,B). This unmarked zone is examined. In an optimal repair there should more than $4 \mathrm{~mm}$ of leaflet beyond the marked line (because some ink enters the coaptation zone, the ink test underestimates the true coaptation surface by a few millimeters). In the case of minimal tissue identified beyond the closure line, adjunct techniques are applied to improve the surface of coaptation, such as further leaflet mobilization by cutting secondary chordae, downsizing of the annuloplasty ring, and cleft closure. The ink test also allows confirmation that no more than $1 \mathrm{~cm}$ of anterior leaflet tissue is below the coaptation line (Figures 1, B). Because excessive anterior leaflet tissue distal to the coaptation line can predispose to systolic anterior motion, if identified, this should be corrected by height reduction of either leaflet.

\section{Discussion}

An adequate mitral valve repair should result in a competent valve with a symmetric line of closure and adequate surface of coaptation. Symmetry of the closure line and competency are demonstrable on saline testing. ${ }^{2}$ Our ink test provides further clarification of the quality of repair by confirming an optimal surface of coaptation below the closure line (a 1-mm coaptation surface might be "competent" but not optimal). An adequate surface of coaptation is essential for a durable 


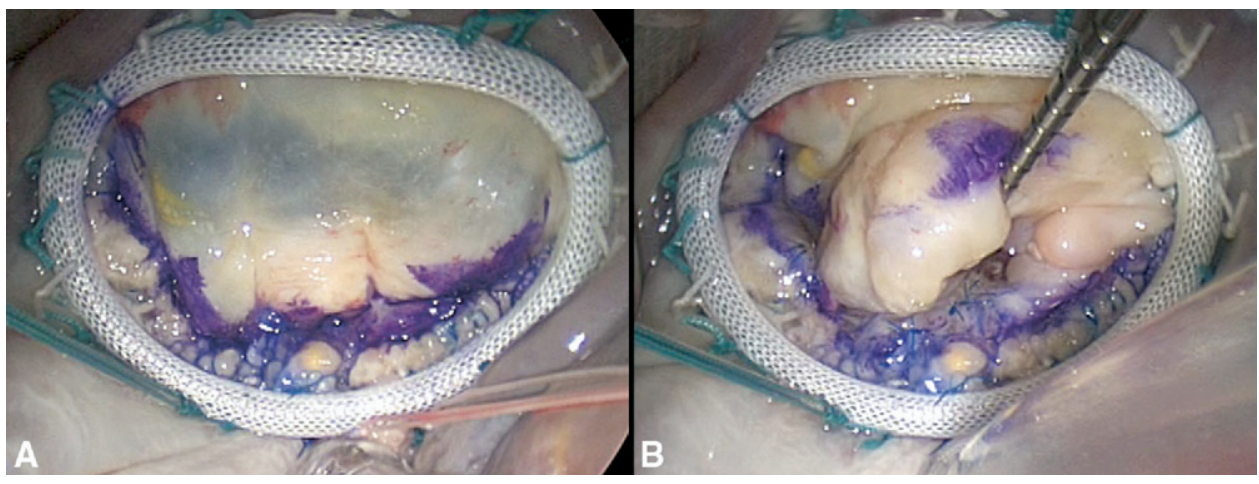

Figure 1. The ink test in Barlow's mitral valve repair. Panel A shows a marked closure line after a repair of a Barlow's valve by using sliding valvuloplasty and a Carpentier-Edwards Physio ring (Edwards Lifesciences, Irving, Calif). The closure line is symmetric, and the ratio of posterior to anterior leaflet is optimal. Panel B shows an adequate surface of coaptation of both leaflets beyond the marked line. Notably, there is no more than $1 \mathrm{~cm}$ of anterior leaflet below the marked line, making the possibility of systolic anterior motion remote.

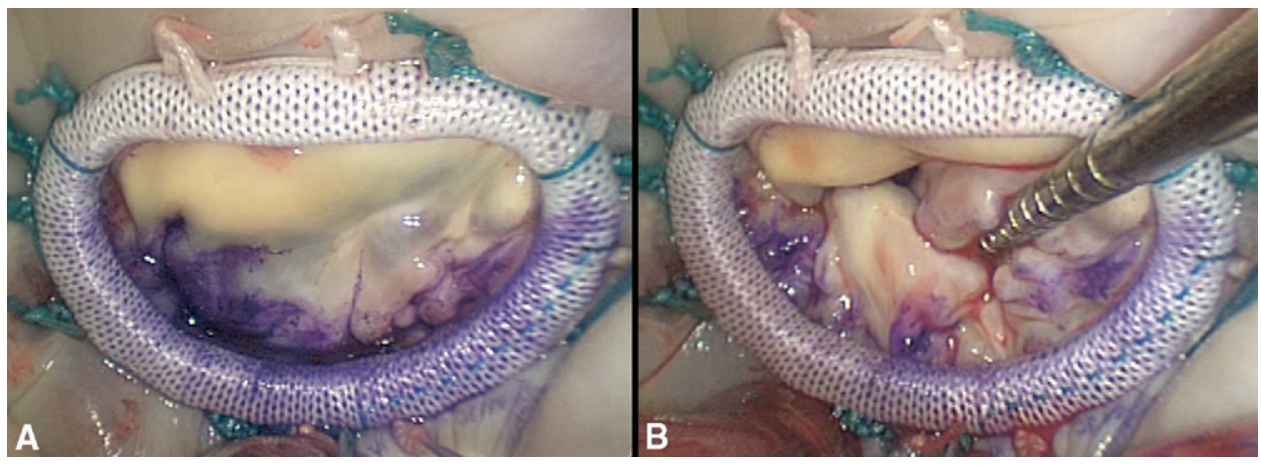

Figure 2. The ink test in ischemic mitral valve repair. Panel A shows a marked closure line in an ischemic mitral valve repaired with a Carpentier-McCarthy-Adams Etlogix ring (Edwards Lifesciences, Irving, Calif). A symmetric line of closure is demonstrated very close to the posterior annulus, implying most of the (restricted) posterior leaflet is now involved in coaptation. Panel B demonstrates that an adequate surface of posterior leaflet beyond the marked line is available for coaptation.

repair, ${ }^{2-4}$ particularly in type IIIb dysfunction, in which a minimal surface of coaptation will likely predispose to recurrent mitral regurgitation in the event of adverse ventricular remodeling., ${ }^{3,5}$ The ink test therefore might provide useful information that enables the surgeon to further optimize the repair result during valve reconstruction. Given the unlikelihood that the surgeon will reinstitute cardiopulmonary bypass in the setting of minimal surface of coaptation in a competent valve seen on postbypass TEE, the ink test provides the surgeon with a method of detecting and correcting deficiencies in the coaptation surface that would otherwise have been accepted (if first detected on TEE). We believe our test has the potential to facilitate higher-quality valve reconstruction, which might have long-term implications in terms of freedom from recurrent mitral regurgitation. Further study is necessary to correlate the ink test approach with echocardiographic and clinical outcomes.

\section{References}

1. Adams DH, Anyanwu A. Pitfalls and limitations in measuring and interpreting the outcomes of mitral valve repair. J Thorac Cardiovasc Surg. 2006;131:523-9.

2. Carpentier A. Cardiac valve surgery-the "French correction." J Thorac Cardiovasc Surg. 1983;86:323-37.

3. Anyanwu A, Rahmanian PB, Filsoufi F, Adams DH. The pathophysiology of ischemic mitral regurgitation: implications for surgical and percutaneous intervention. J Interv Cardiol. 2006;19(suppl):S78-86.

4. Yamauchi T, Taniguchi K, Kuki S, Masai T, Noro M, Nishino M, et al Evaluation of the mitral valve leaflet morphology after mitral valve reconstruction with a concept "coaptation length index." J Card Surg. 2005;20:432-5.

5. Hung J, Papakostas L, Tahta SA, Hardy BG, Bollen BA, Duran CM, et al. Mechanism of recurrent ischemic mitral regurgitation after annuloplasty: continued LV remodeling as a moving target. Circulation. 2004; 110(suppl II):II85-90. 